\title{
Development of Active Biodegradable Films: Starch Films Incorporated with Starch Nanoparticles and Oregano Essential Oil
}

\author{
Karina Lizzeth Pedraza Galván ${ }^{1 *}$; Lucas Guimarães Cardoso'; Janaina de Carvalho Alves ${ }^{1}$; Madian Johel Galo \\ Salgado $^{1}$; Pedro Paulo Lordelo Guimarães Tavares'; Renata Quartieri Nascimento²; \\ Jania Betania Alves da Silva ${ }^{3}$; Janice Izabel Druzian ${ }^{1}$ \\ ${ }^{1}$ Federal University of Bahia (UFBA), School of Pharmacy; Salvador, Bahia; ${ }^{2}$ Federal University of Bahia (UFBA), \\ RENORBIO; Salvador, Bahia; ${ }^{3}$ Federal University of Recôncavo Bahia (UFRB); Centro, Cruz das Almas, Bahia; Brazil
}

\begin{abstract}
The present study aimed to develop biodegradable starch films with starch nanoparticles incorporated with oregano essential oil - OEO (Origanum vulgare), for application as active packaging in food preservation. Film production was performed using the casting method. Three concentrations of oregano essential oil $(0.0 \%, 5.0 \%$ and $10 \%)$ were studied. The physical and mechanical properties of the films produced were also evaluated. For analysis of antimicrobial efficiency, the methodologies of CLSI and APHA were used. The incorporation of essential oregano oil influenced the performance of the films. The films with $5.0 \%$ and $10 \%$ OEO showed antimicrobial efficiency when compared to the control.

Keywords: Packaging. Nanoparticles. Antimicrobial. Essential Oil.
\end{abstract}

In recent years, the use of biodegradable packaging has increased $5 \%$ each year [1], with starch, alginate, cellulose ethers, chitosan, carrageenan, or pectins being some of the most commonly used biopolymers in packaging production [2]. Starch has been highlighted for being abundant and having the lowest cost, besides presenting possibilities of chemical, physical, or genetic modification, resulting in resistant and biodegradable films [3].

However, many of these biodegradable polymers have performance-related problems, such as low mechanical and thermal resistance, brittleness and low deformation temperature, and low moisture barrier, limiting the use of biodegradable packaging by industries [4]. Nanotechnology comes through the use of nanoparticles to improve the mechanical and thermal characteristics of these films as an alternative in solving the performance problems of starch films. Due to their nano size, they may Received on 23 August 2019; revised 24 September 2019. Address for correspondence: Dr. Karina Lizzeth Pedraza Galván. Universidade Federal da Bahia (UFBA), Faculdade da Farmácia. Rua Barão de Geremoabo, s/n, Campus de Ondina. Piatã.Salvador, Bahia, Brazil. Zip Code: 40170-210. E-mail: pedrazagalvankarina@gmail.com. This study was selected from the V International Symposium of Innovation and Technology - SIINTEC (October 2019).

J Bioeng. Biotech. Appl. Health 2019;2(3):92-98.

(C) 2019 by SENAI CIMATEC. All rights reserved. have new and improved physical, chemical, and biological properties [5], and better functionality when compared to more extensive material [6].

In addition to improving the properties mentioned above, we also seek to enhance the safety, quality, and shelf life of ready-to-eat foods. According to the Ministry of Health [7], the bacteria Salmonella spp., Escherichia coli, and Staphylococcus aureus are the principal cause of the foodborne disease (FBD). With this, built-in packaging with antimicrobials aims to have higher protection and increase the shelf life of foods. Plant essential oils are an example of natural antimicrobial substances widely studied for food applications [8]. Foods commonly used in the diet of the population, like cheese, are generally present in all social classes [9]. It is characterized as a highly perishable product, contains high levels of protein and lipids, undergoes many deterioration reactions, some of them with high humidity, and has essential nutrients for microbial development [10]. Proper packaging for this type of food is of great importance to maintain the quality during storage. The objective of the present study was to develop biodegradable starch films with starch nanoparticles and oregano essential oil (Origanum vulgare), for application as an active packaging for preservation, aiming at controlling the microbial population in mozzarella cheese. 


\section{Methods}

The analyses were performed in the Fish and Applied Chromatography Laboratory (LAPESCA). Corn starch (DURYEA®), starch nanoparticles, glycerol (SYNTH®) were used as a plasticizer, and oregano essential oil was used as an antimicrobial agent (FERQUIMA ${ }^{\circledR}$ ). Corn starch nanoparticles were prepared by the ultrasound method in a Q55 Sonicator (United States), according to the methodology of Pereira and colleagues [11]. The colloidal suspension was frozen and freeze-dried to obtain nanoparticles with diameters of approximately $400 \mathrm{~nm}$.

\section{Preparation of the Films}

The films were prepared according to the casting technique, which consists of the preparation of a filmogenic solution by dissolving the cornstarch in distilled water, starch nanoparticles, and the glycerol plasticizer and oregano essential oil as antimicrobial agent. The films were developed with a concentration of $4.0 \mathrm{~g}$ starch, $0.25 \mathrm{~g}$ starch nanoparticles and $2.1 \mathrm{~g}$ glycerol $/ 100 \mathrm{~g}$ filmogenic solution. The films were prepared with three different concentrations of oregano essential oil $(0.0,5.0$, and $10.0 \%)$, respectively, concerning the total filmogenic solution.

\section{Mechanical Properties}

The films were characterized for thickness upon reading with a manual micrometer (Mitutoyo Corp.) and subjected to maximum tensile strength, rupture deformation, and modulus of elasticity load according to ASTM D882-09 [12] using the Universal Testing Machine. (INSTRON Corporation, Norwood, MA, USA). Ten specimens of each formulation with dimensions of $10 \mathrm{~cm}$ long and $2.5 \mathrm{~cm}$ wide were tested. The machine was operated at $1 \mathrm{kN}$ load at a pulling speed of 5 $\mathrm{mm} / \mathrm{min}$.

\section{In vitro Antimicrobial Analysis}

The antimicrobial activity of the essential oil films was evaluated using the agar diffusion test of the prepared films. We used Escherichia coli, Staphylococcus aureus, and Salmonella spp' cultures. According to the methodology of the Clinical and Laboratory Standards Institute (CLSI) Manual [13], inocula of each microorganism were prepared by direct suspension, in sterile saline, of isolated colonies selected from Trypticase Soy Agar (TSA) plates, and incubated at $35^{\circ} \mathrm{C}$ for 18 $24 h$.

\section{In vivo Antimicrobial Analysis}

The films were cut to a sufficient size to cover the surfaces of the mozzarella cheese slices. The food covered in the antimicrobial films was stored at $8 \pm 2^{\circ} \mathrm{C}$. Microbiological analyses of cheese were performed according to the methodology described by the American Public Health Association (APHA) [14] at 0, 7, 14, 21 days.

\section{Results and Discussion}

The visual aspect of the $0 \%$ film (Figure 1A) composed of starch, $0.25 \mathrm{~g}$ of starch nanoparticles, and $0 \mathrm{~g}$ of OEO (control film) showed the best homogeneity, transparency, brightness, flexibility, and no difficulty in removing the drying plate. The 5\% film (Figure 1B) had slightly lower homogeneity when compared to the control film. Besides, it presented great flexibility, transparency, brightness, and little difficulty to remove in the drying plate. The $10 \%$ film (Figure 1C) showed less homogeneity when compared to the other films, showed the change in color due to a higher concentration of OEO, and with greater difficulty to remove the drying plates.

\section{Mechanical Properties}

The results of the mechanical tests show that the increase of OEO concentration decreased the maximum tensile strength, rupture deformation, and modulus of elasticity of the films (Figure 2). The formulations $5 \%$ and $10 \%$ presented inferior results when compared to the control (F0). Starch nanoparticle studies by $\mathrm{Li}$ and colleagues [15] showed that films with $5.0 \%$ nanoparticles had 
Figure 1. Embedded starch films of starch nanoparticles, glycerol, and $0 \%$ (A), 5\% (B), and 10\% (C) oregano essential oil as antimicrobial agent.

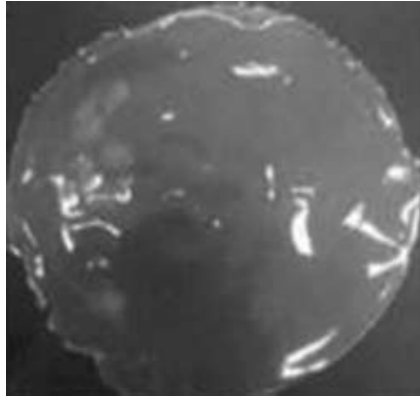

(A)

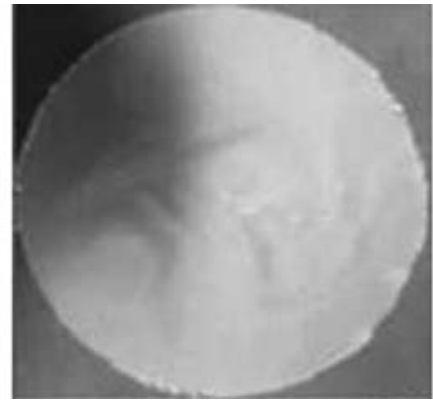

(B)

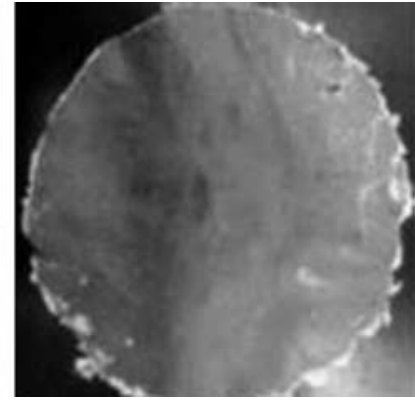

(C) a maximum tensile strength of $9.96 \mathrm{MPa}$, an increase of $72.9 \%$ compared to the control film without nanoparticles, and the rupture deformation decreased $12.58 \%$, showing that the addition of OEO contributed to the reduction of these parameters.

Dai and colleagues[16] found that the addition of $10 \%$ starch nanoparticles increased the maximum tensile strength to $2.87 \mathrm{MPa}$, the justification for the improvement of the mechanical properties of the film was due to the high specific surface area provided by the nanoparticles, causing higher resistance. The concentration of nanoparticles used has a strong influence on the properties of the films [17].

Results similar to the present study were presented by Martucci and colleagues [18], in which the mechanical properties of biogenic gelatin films with essential oregano oil as an antimicrobial agent were evaluated. According to the authors, the addition of oil significantly affected the tensile strength and the stretching ability of the films obtained. The incorporation of the oil possibly resulted in decreased interaction between gelatin monomers, preventing polymer chain-chain interactions, and consequently, compromised mechanical properties. Similarly, in the starch films produced, the incorporation of OEO possibly resulted in decreased interaction between the starch glucose monomers, resulting in decreased strength.
In vitro Antimicrobial Activity

We observed that the higher concentration of essential oregano oil was the sensitivity of in vitro antimicrobial activity (Table 1). $S$. aureus was the microorganism that presented the highest sensitivity to the film, with halos of $26 \mathrm{~mm}$ and $36 \mathrm{~mm}$ in concentrations of $5 \%$ and $10 \%$ of oregano essential oil, respectively (Table 1). In a study by Botre and colleagues [19], antimicrobial activity against $S$. aureus was also found in films with $50 \%$ oregano essential oil. The authors found that the film incorporated with $25 \%$ oregano essential oil formed a larger inhibition halo, demonstrating that the higher the essential oil concentration, the greater the antimicrobial activity.

According to Medeiros [20], the cellulose acetate film incorporated with $50 \%$ oregano essential oil showed antimicrobial activity on $S$. aureus, obtaining an average inhibition halo of 20 $\mathrm{mm}$. Also, showing antimicrobial activity against Staphylococcus aureus. Javidi and colleagues [21] analyzed the microbiological effectiveness of PLA (polylactic acid) films obtained by the casting method, incorporated with OEO, against $S$. aureus, Listeria monocytogenes, E. coli and $S$. enteritidis. They obtained a better antimicrobial action against Gram-negative bacteria. Different from the present study, where antimicrobial films showed better effectiveness against Gram-positive bacteria ( $S$. aureus), and it may be related to the 
Figure 2. Mechanical Properties - Maximum tensile strength (A), Rupture deformation (C). Modulus of elasticity of starch films incorporated with starch nanoparticles and with $0 \%$ (F0), 5\% (F5), and 10\% (F10) of oregano essential oil.
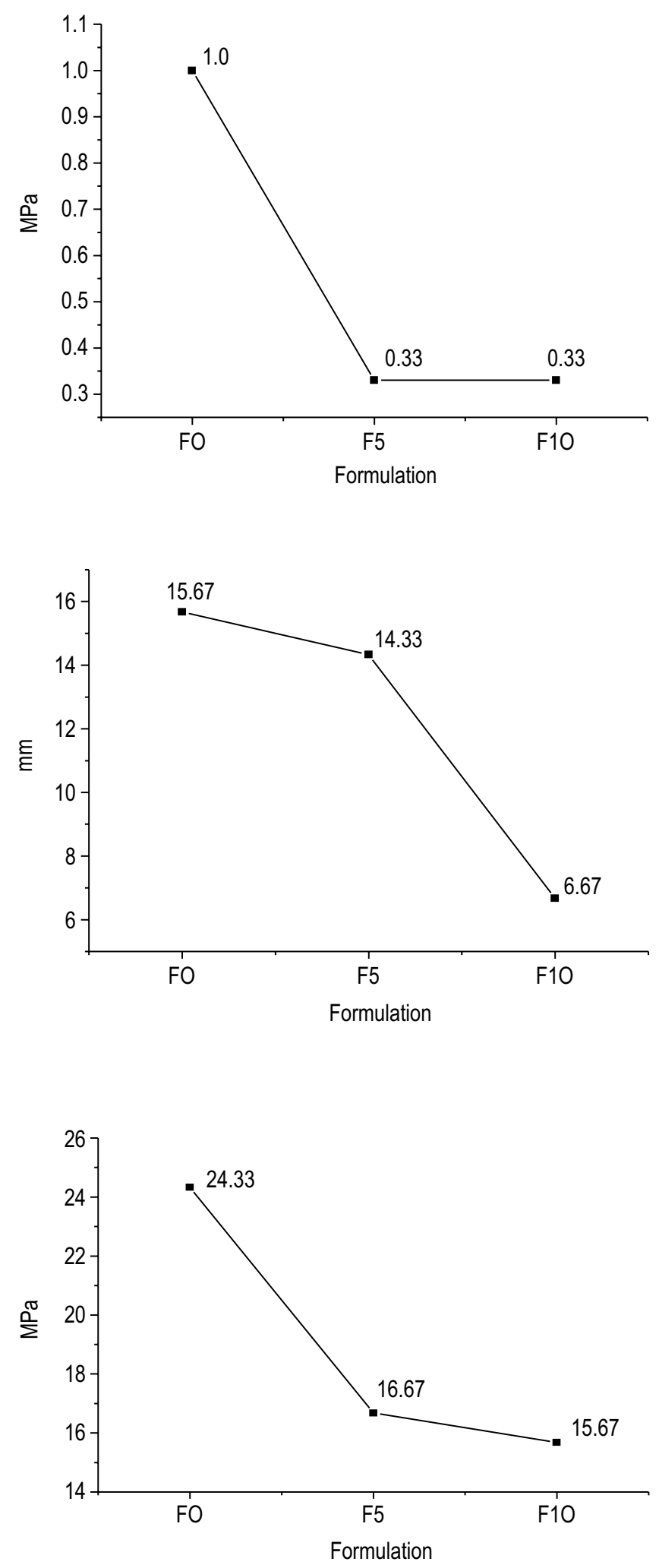

www.jbth.com.br 
Table 1. Measurements of microbial growth inhibition halos of Escherichia coli, Staphylococcus aureus and Salmonella spp, under different percentages of oregano essential oil in starch films, starch nanopaticles.

\begin{tabular}{lccc}
\hline & $\begin{array}{c}\text { Escherichia } \\
\text { coli }(\mathbf{m m})\end{array}$ & $\begin{array}{c}\text { Staphylococcus } \\
\text { aureus }(\mathbf{m m})\end{array}$ & $\begin{array}{c}\text { Salmonellas } \\
\mathbf{p p}(\mathbf{m m})\end{array}$ \\
\hline Film $0 \%$ & 0 & 0 & 0 \\
Film 5\% & 21 & 26 & 21 \\
Film 10\% & 28 & 36 & 24 \\
\hline
\end{tabular}

Means from duplicates.

form of obtaining the films and the interaction between the polymer and the essential oil.

According to Silva [22], the antibacterial action of the essential oils varies significantly based on the bacteria, being the sensitivity higher for Grampositive than Gram-negative bacteria. One possible explanation for the observed differences in bacterial sensitivity may be differences in the bacterial wall structure, such as the presence of lipopolysaccharide in Gram-negative bacteria and the absence of Gram-positive bacteria, which may allow substances to enter or not in the bacterial cell, thus interfering with the action on the microorganism.

Antimicrobial Activity in the Food Matrix

Microbiological analysis of the sliced mozzarella cheese was performed at time 0 (Table 2), which followed the microbiological limits established by RDC-12, which establishes $S$. aureus limits of $10^{3} \mathrm{CFU} / \mathrm{g}$, Thermotolerant Coliforms of $5 \times 10^{2} \mathrm{CFU} / \mathrm{g}$ and no Salmonella spp. $25 \mathrm{~g}$ in mozzarella cheese [24].

Films containing $10 \mathrm{~g}$ OEO had different variations in their antimicrobial effectiveness

Table 2. Microbiological analysis of cheese within 0 days.

\begin{tabular}{lc}
\hline Thermotolerant Coliforms & Absent \\
\hline Total Coliforms & $2.0 \times 10^{-1}$ \\
S.aureus & $1.7 \times 10^{-2}$ \\
Salmonella spp & Absent \\
Mesophiles & $2.0 \times 10^{-2}$ \\
\hline
\end{tabular}

when compared to films containing $5 \mathrm{~g}$ OEO in vivo and in vitro tests. However, films containing $5 \mathrm{~g}$ and $10 \mathrm{~g}$ of OEO were active until the $14^{\text {th }}$ day. It extended the shelf life of the cheese by 12 days, following current RDC legislation No. 12. Melo [25] failed to extend the shelf life of chilled chicken meat by storing added cellulosic base film. 20\% rosemary essential oil within nine days of storage, although inhibition has been proven in vitro tests. Thus, we believed that the type of food matrix is an important factor that can interfere in this process, as interactions between antimicrobial compounds and food components, such as proteins and fats, may influence the effectiveness of these compounds.

According to Cardoso an colleagues [26], PBAT films incorporated with different OEO concentrations, in which fish fillets were packed, were also effective in decreasing total coliform counts, Staphylococcus aureus and psychrotrophic microorganisms. It led to an increase in fillet life for up to 10 days, which shows us that OEO has a useful in vivo antimicrobial action. Botre and colleagues [19], who analyzed 25 and $50 \%$ OEO-added cellulosic resin films packaged in ready-made pizzas, did not obtain inhibition of psychrotrophic growth. However, the growth of filamentous fungi and yeast showed little inhibition after 15 days of storage at $7^{\circ} \mathrm{C}$ when submitted to $50 \%$ oregano treatment. In contrast, a study by Soares and colleagues [27], revealed a reduction of 0.5 and $1.0 \mathrm{log}$ cycle in Listeria innocua growth in fresh cheese packaged in the presence of OEO- 
containing films, in relation to control, at the end of the storage period ( $12^{\text {th }}$ day), confirming the potential use of OEO as an antimicrobial agent in active packaging.

\section{Conclusion}

The incorporation of essential oregano oil interferes with the performance of starch films and starch nanoparticles, reducing the mechanical resistance. The 5\% OEO and $10 \%$ OEO films showed antimicrobial efficiency in vitro and in vivo analyses, thus demonstrating their potential as a tool for maintaining food quality. The films represent an alternative for reducing the use of conventional plastics in the packaging of some foods. However, there is a need for further studies to evaluate the action of these films in other food matrices.

\section{References}

1. Da Rocha, M. et al. Biodegradable Films: An Alternative Food Packaging. In: Food Packaging and Preservation. Academic Press. 2018;:307-342.

2. Vieira, M.G.A., et al. Natural-based plasticizer sand biopolymer films: A review. European Polymer Journal. 2011;47(3):254-263.

3. Mali, S., et al. Water sorption and mechanical properties of cassava starch films and their relation to plasticizing effect. Carbohydrate polymers. 2005;60(3):283-289.

4. Assis, L.M., et al. Characteristics of nanoparticles and their potential applications in foods. Brazilian Journal of Food Technology. 2012;15(2):99-109.

5. Miyazaki, K., Islam, N. Nanotechnology systems of innovation-Annalysis of industry and academia research activities. Technovation. 2007;27:661-675.

6. Boccuni, F., Rondinone, B., Petyx, C., Iavicoli, S. Potential occupation alexposureto manufactured nanoparticles in Italy. Journal of Cleaner Production. 2008;16:949-956.

7. Brasil. Ministério da Saúde. DoençasTransmitidas por Alimentos.http://portalarquivos2.saude.gov.br/images/ pdf/2018/janeiro/17/Apresentacao-SurtosDTA-2018. pdf. Accessed on Mar. 15, 2018.

8. Chen, C.P., Wang, B.J., Weng, Y.M. Physiochemical and antimicrobial properties of edible aloe/gelatin composite films. International Journal of Food Science and Technology, Oxford. 2010;45(1050-1055).
9. Silva, J.F.Q., Filizola, L.R.S., Maia, M.M.D., Sena, M.J. Utilização de coliformes termotolerantes como indicadores higiênico-sanitários de queijo Prato comercializado em supermercados e feiras livres de Recife-PE. Revista de MedicinaVeterinária. 2011;1(2125).

10. Sangaletti, N., et al. Estudo da vida útil de queijo Minas. Ciência e Tecnologia de Alimentos. 2009;29(2):262269.

11. Bel H.A.A.J.S., Magnin, A., Petrier, C., Boufi, S. Starch nanoparticles formation via high power ultrasonication. Carbohydrate Polymers. 2013;92:1625-1632.

12. ASTM D882-09. Standard test method for tensile properties of thin plastics heeting. 468 Annual Book of ASTM Standards. Amer. Soc. for Testing and Materials. Philadelphia, PA. 2009.

13. CLSI. Perfomance Standards for Antimicrobial Susceptibility Testing; Twenty Third Infomational Supplement. CLSI document M100-S23. Clinical nd Laboratory Standards Intitute, Wayne, PA, USA. 2013.

14. AmericanPublicHealthAssociation(APHA).Compendium of methods for the microbiologica examination of foods. $4^{\text {th }}$ Ed. Washington: APHA. 2001:676.

15.Li, X., Qiu, C., Ji, N., Sun, C., Xiong, L., Sun, Q. Mechanical, barrier and morphological properties of starch nanocrystals-reinforced peastarch films. Carbohydrate Polymers. 2015;121:155-162.

16. Dai, L., Qiu, C., Xiong, L., Sun, Q. Characterization of cornstarch-based films reinforced with taro starch nanoparticles. Food Chemistry. 2015;174:82-88.

17. Le Corre, D., Bras, J., Dufresne, A. Starch nanoparticles: A review. Biomacromolecules. 2010;11:1139-1153.

18. Martucci, J.F., Gende, L.B., Neira, L.M., Ruseckaitea, R.A. Oregano and lavender essential oils as antioxidant and antimicrobial additives of biogenic gelatin films. Industrial Crops and Products. 2015;71:205-213.

19. Botre, D.A., Soares, N.F.F., Espitia, P.J.P., Sousa,S., Renhe, I.R.T. Avaliação de filme incorporado com óleo essencial de orégano para conservação de pizza pronta. Revista Ceres. 2010;57(3):283-291.

20. Medeiros, E.A.A., et al. Atividade antimicrobiana de filme de acetado de celulose incorporado com oléo essencial de óregano (Origanum vulgare L.) em queijo minas frescal. Xxv CBCTA - Ufrgs, Gramado, p.1-6, out. 2016.

21. Javidi, Z., Hosseini, S.F., Rezaei, M. Development of flexible bactericidal films based on poly (lactic acid) and essential oil and its effectiveness to reduce microbial growth of refrigerate drainbow trout. LWT Food Science technology. 2016;72:251-260.

22. Silva, M.T.N., et al. Atividade antibacteriana de óleos essenciais de plantas frente a linhagens de Staphylococcus aureus e Escherichia coli isoladas de casos clínicos humanos. Rev. Bras. Plantas Me. 2009;11(3):257-262. 
23. Fernandez-Saiz, P., Ocio, M.J., Lagaron, J.M. Antibacterial chitosan based blends with Ethylenevinyl alcohol copolymer. Carbohydrate Polymers. 2010;80(3):874-884.

24. Brasil. Agência Nacional de Vigilância Sanitária. Resolução - RDC no. 12, de 2 de janeiro de 2001. Regulamento técnico sobre os padrões microbiológicos para alimentos. http://www.anvisa.org.br. Accessed on Mar.15,2018.

25. Melo, A.A.M. Efeito de filme ativo incorporado com óleo essencial de alecrim (Rosmarinus officinalis L.) na conservação de carne de frango resfriada. Dissertação (Mestrado em Ciência e Tecnologia de Alimentos)
- Escola de Agronomia e Engenharia de Alimentos, Universidade Federal de Góias, Goiânia-GO, 2010.

26. Cardoso, L.G., Santos, J.C.P., Camilloto, G.P., Miranda, A.L., Druzian, J.I., Guimarães, A.G. Development of active films poly (butyleneadipateco-terephthalate) - PBAT incorporated with oregano essential oil and application in fish fillet preservation. Industrial Crops \& Products. 2017;108:388-397.

27. Soares, N.F.F., Silva, P.S.S. Desenvolvimento e avaliação de filme ativo incorporado com óleo essencial de orégano (Origanum vulgare L.) no crescimento de Listeria innocua em queijo Minas frescal. Revista do Instituto de Laticínios Cândido Tostes. 2008;365(63):36-40. 